\title{
Az ultrahangmódszerek szerepe a férfimeddőség kivizsgálásában
}

\author{
Fejes Zsuzsanna dr. ${ }^{1}$ - Pásztor Norbert dr. ${ }^{2}$ \\ Karczagi Lilla dr. ${ }^{1}$ - Brzózka Ádám dr. ${ }^{1}$ - Király István dr. ${ }^{3}$ \\ Morvay Zita dr. ${ }^{4}$. Palkó András dr. ${ }^{4}$
}

${ }^{1}$ Affidea Diagnosztika, Szeged

Szegedi Tudományegyetem, Általános Orvostudományi Kar, Szent-Györgyi Albert Klinikai Központ, ${ }^{2}$ Szülészeti és Nőgyógyászati Klinika, ${ }^{3}$ Urológiai Klinika, ${ }^{4}$ Radiológiai Klinika, Szeged

\begin{abstract}
Az önkéntelen gyermektelenség a reproduktív korban lévő párok nagyjából 9-15\%-át érinti. Ismert, hogy a gyermektelenség jelentős részének hátterében a férfi reprodukciós múködési zavara áll. A férfimeddôség kivizsgálásának elengedhetetlen részét képezik a képalkotó módszerek, melyek közül is a gyakorlatban az ultrahangvizsgálatok bírnak kiemelt jelentőséggel. A jelen tanulmányban az elsődleges célunk, hogy összefoglaljuk az ultrahang-diagnosztika szerepét a gyermektelenség okának tisztázásában. Technikai és metodikai szempontok szerint csoportosítva bemutatjuk azokat a vizsgálati eredményeket, melyek a páciens további kivizsgálását és kezelését alapvetően befolyásolhatják. A here vizsgálatában új, ígéretes módszernek tekinthető a szonoelasztográfia. A strain elasztográfia a szövet rugalmasságát jeleníti meg, melynek alapján a vizsgált terület szöveti szerkezetéről additív információ nyerhető. A módszer a hagyományos ultrahangvizsgálat kiegészítéseként egyre több helyen elérhető, de szerepe a férfimeddőség kivizsgálásának menetében még nem meghatározott.
\end{abstract}

Orv Hetil. 2018; 159(21): 815-822.

Kulcsszavak: férfimeddőség, ultrahangvizsgálat, strain és shear wave elasztográfia

\section{The role of ultrasonography in the investigation of male infertility}

\begin{abstract}
Unintended childlessness affects approximately $9-15 \%$ of couples in the reproductive age. It is known that a remarkable proportion of infertility is caused by the disorders of the male reproductive functions. Diagnostic imaging methods and especially ultrasonography play a crucial role in the infertility work-up, the ultrasound examination has become the method of choice for imaging in diseases affecting the testis. With the development of high resolution transducers and technology using colour Doppler, pulsed Doppler, share wave elastography and strain elastography, it is now possible to make accurate diagnoses. However, the place of the new imaging methods in the algorithm of infertility check-up should be clearly defined.
\end{abstract}

Keywords: male infertility, ultrasound examination, strain and shear wave elastography

Fejes Zs, Pásztor N, Karczagi L, Brzózka Á, Király I, Morvay Z, Palkó A. [The role of ultrasonography in the investigation of male infertility]. Orv Hetil. 2018; 159(21): 815-822.

(Beérkezett: 2018. január 31.; elfogadva: 2018. március 2.)

\section{Rövidítések}

$\mathrm{AFP}=$ alfa-fetoprotein; béta-hCG = béta-koriongonadotropin; FSH = folliculusstimuláló hormon; $\mathrm{LDH}=$ laktátdehidrogenáz; $\mathrm{RI}=$ rezisztenciaindex; $\mathrm{SWE}=$ shear wave elasztográfia

\section{Történeti áttekintés}

Meddőségről akkor beszélhetünk, ha egy párkapcsolatban 1 éven belül rendszeres, gyermeket óhajtó szexuális élet ellenére sem jön létre terhesség. Ezen belül 40-58\%- 
ban nói, 25-40\%-ban férfieredetünek tulajdonítják, a fennmaradó 15-20\%-ban a meddőség oka rejtve marad [1]. A mögöttes ok feltárásának során mind a női, mind a férfi fél kivizsgálásra kerül [2]. Az utóbbi évtizedekben a férfiak kivizsgálása a képalkotó diagnosztika fejlődésének köszönhetően igen sokat változott, és egyre több esetben derül fény az infertilitás okára $[1,3]$.

Az első próbálkozások a meddőségi diagnosztikában az ondóutak eltéréseit, illetve elzáródását próbálták kimutatni. Mivel ezek a vizsgálatok egyrészt röntgensugárzással jártak, kivitelezésük bonyolult volt, másrészt nem volt ritka a súlyos szövődmény előfordulása sem, használatuk a jelenlegi andrológiai gyakorlatból eltűnt. Ugyanakkor az ultrahang-technológia fejlődése és elterjedése nagy változást hozott az infertilitási vizsgálatokban is.

Kratochwil 1975-ben még csak a prostataméret meghatározását emelte ki az ultrahang-diagnosztikából, a herék vizsgálatára csak szúk körben vélte alkalmazhatónak [4]. Ennek ellenére két évvel később már a B-módú herevizsgálat diagnosztikus hasznát emelték ki a hereduzzanatok kivizsgálásában [5]. Az első esettanulmány 1986-ban jelent meg, melyben egy $10 \mathrm{MHz}$ frekvenciájú transzducerrel microlithiasis volt látható a B-módú képeken [6]. Kis időnek kellett eltelnie az első publikációhoz, mely összefüggést feltételez az ultrahanggal látott microlithiasis és a spermiumtermelés zavara között [7]. Az ultrahangos Doppler-technikát első alkalommal 1974ben alkalmazták a here vérellátásának vizsgálatában, torsio testis kimutatására [8]. A tárgyban az első magyar összefoglaló 1989-ben jelent meg a Magyar Urológiában, mely részletesen összefoglalja a here és a mellékhere elváltozásait [9], ekkor az ultrahang használata és pontos feladata a meddőségi diagnosztikában még nem volt teljesen világos.

A technika fejlődésével a következő nagy változás a 2000-es évek elejére tehető, az ultrahang-kontrasztanyagos technikák egyre nagyobb teret kezdtek hódítani [10, 11]. Az első tanulmány, mely az infertilitási vizsgálatokban alkalmazta az új eljárást, 2009-ben jelent meg. Beszámolt arról, hogy a módszer ígéretesnek tünik a meddőségi diagnosztikában, jól detektálhatók a testicularis érrendellenességek, valamint vizsgálható a károsodott mikrocirkuláció, mely a spermatogenesis károsodásához vezethet [12]. Egy másik kutatócsoport a heretumorok differenciáldiagnosztikájában látja a kontrasztanyagos ultrahangvizsgálatok jövőjét, mivel a malignus eltéréseket, mint például a seminomát a dús érhálózata miatt, az ultrahang-kontrasztanyag intenzíven kirajzolja, majd viszonylag gyorsan ki is mosódik, ami a differenciáldiagnózisban fontos segítség lehet [13].

\section{Az ultrahangvizsgálat szerepe}

A scrotum vizsgálatában az ultrahangvizsgálat könnyen, gyorsan, költséghatékonyan hozzáférhető eljárás [14]. A vizsgálat jól reprodukálható, elengedhetetlenül fontos a hereleszállási zavarokkal diagnosztizált páciensek és a herefájdalommal jelentkező betegek körében. Eredménye a pontos diagnózis felállítását nagyban segíti, azonban heretumorok szürővizsgálatára nem alkalmas.

A következőkben a meddőségi kivizsgálás részeként végzett ultrahangvizsgálatokat technikai-metodikai alapok szerint csoportosítva mutatjuk be.

\section{B-módú vizsgálatok}

A legáltalánosabban használt vizsgálati eljárás, mely minden ultrahanggépen hozzáférhető; önmagában nagyon ritkán használjuk, sőt kizárólagos használata megnehezíti az intratesticularis eltérések differenciáldiagnózisát. A B-módú vizsgálat során egy metszeti képet kapunk, amelyen a fényesebb pontok a nagyobb mértékü ultrahangnyaláb visszaverődését jelzik. A különböző fényességű pontokat szürke skálának feleltetjük meg [15]. A scrotumvizsgálathoz magas frekvenciájú, 7,5-15 MHz lineáris fej használata ajánlott [15-17]. A vizsgálat során mind a két heréról hossz- és keresztmetszetben készítünk képeket, lehetőség szerint térfogatot számolunk, és összehasonlító felvételeket készítünk [18]. A klinikai kérdés többek között a microlithiasis meglétére irányul. Ennek felismerése klasszikus esetekben könnyü. A microlith a here kanyarulatos csatornáiban elhalt, nem fagocitált sejtekből, glikoproteinekből, illetve kalcifikálódott hidroxiapatitkristályokból áll [19]. A here ultrahangvizsgálata során a leggyakrabban keresett eltérés a microlithiasis, melynek előfordulása a normálpopulációban alacsonyabb, mint az infertilis férfiak körében. A here ultrahangvizsgálatára küldött férfiak között a prevalenciája 0,6-9\% [20]. Patomechanizmusa, etiológiája nagyrészt ismeretlen, létrejöttében feltehetőleg genetikai és környezeti tényezők együttesen játszanak szerepet [21]. Van Casteren 2009-es definíciója szerint valamennyi 3 $\mathrm{mm}$ alatti, fokozott echogenitású, hangárnyékot nem adó, intratesticularis eltérést microlithiasisnak kell tartani, függetlenül azok számától [22]. Megkülönböztethetünk klasszikus típust (képenként több, mint 5 microlith) és limitált típust (képenként 5 vagy annál kevesebb microlith). A közleményekben találkozhatunk még Grade I-IV besorolással, mely az egy képen észlelt microlithek száma alapján a következő kategóriákat különbözteti meg: limitált (3-4 microlith), Grade I (5-10 microlith), Grade II (11-20 microlith) és Grade III (20-30 microlith), Grade IV (>30 microlith) [23]. Az objektív, reprodukálható osztályozásra való törekvések még napjainkban is jelen vannak. Az intra- és interobszerver vizsgálatok során azt találták, hogy a szakmailag tapasztaltabbak nem fedeztek fel szignifikánsan több microlithiasist a kevés gyakorlattal rendelkezőkkel szemben, azonban a későbbi időpontban történő második vizsgálat során több microlithiasis került leírásra, ami a grading rendszer reprodukálhatóságát megkérdőjelezi [24]. Azt is kimutatták, hogy a Backus által bevezetett osztályozás nincs korrelációban a tumorok prevalenciájával, így a klinikai vizsgálatok során eltekinthetünk alkal- 


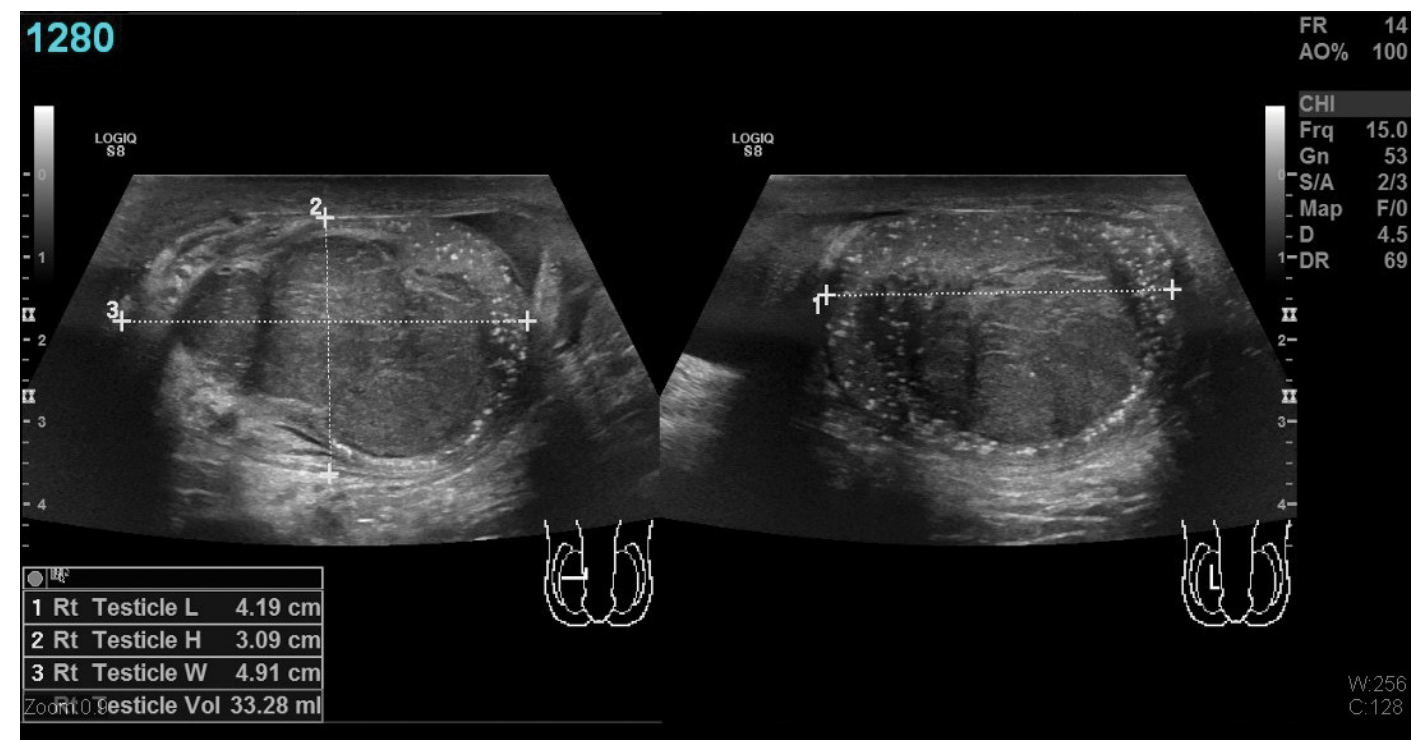

1. ábra

Microlithiasis talaján kialakult, előrehaladott intratesticularis térfoglaló folyamat képe egy 55 éves férfi betegben. Panaszai - elmondása szerint - három hete kezdődtek, az AFP-szint a normáltartományon belül van, a béta-hCG-szint kismértékben emelkedett. A jellegzetes ultrahangkép alapján: homogén szerkezet, karéjozott kontúrok, a meszesedés és cisztás területek hiánya alapján seminoma valószínúsíthető, melyet a mútétet követő patológiai feldolgozás is megerösített

mazásától, elég csupán a limitált és a klasszikus típusok megkülönböztetése [25]. Az irodalmi adatok alapján azonban egyértelmú, hogy a microlithiasis a heretumorok rizikófaktorának tekinthető, igaz, az még nem teljesen világos, hogy az önálló rizikófaktor vagy a testicularis dysgenesis része. Indokolt a microlithiasissal diagnosztizált betegek rendszeres ultrahangos követése, valamint a tumormarkerszintek ellenőrzése: alfa-fetoprotein (AFP): normálérték: $<7 \mathrm{ng} / \mathrm{ml}$; béta-koriongonadotropin (béta-hCG): normálérték: <2,6 IU/l; laktátdehidrogenáz (LDH): normálérték: 125-220 U/1. A követési frekvencia gyakoriságában az adatok ellentmondásosak [22, 25, 26] (1. ábra).

A meddőségi kivizsgálás során néhány esetben találkozhatunk nem tapintható intratesticularis eltérésekkel. Erre azért is érdemes odafigyelni, mivel a microlithiasis és a pathozoospermiák gyakran járnak együtt emelkedett heretumor-rizikót okozó klinikai állapottal (cryptorchismus, hereatrophia, testicularis dysgenesis szindróma) [26]. Ezek felismerése és differenciáldiagnózisa szintén nagyon fontos. Panaszmentes betegben szerencsés esetben korai diagnózist állíthatunk fel. A vizsgálatok során fóként a nagyobb tumortípusokkal találkozhatunk, ezek közül is a leggyakoribb a seminoma, mely nagyon gyakran klasszikus microlithiasissal jellemezhető herében fordul elő. A seminomának is jellegzetes ultrahangképe van. Kontúrja általában lobulált, benne meszesedés vagy cysticus laesio ritkán van jelen, és csak néha többgócú [27]. Nem minden intratesticularis eltérés egyértelmúen malignus, ennek elkülönítésében a Doppler-mód használata lehet segítségünkre. Általánosságban igaz, hogy ha az intratesticularis echószegény eltérésben fokozott vascularisatio látszik, az malignitásra utal. Csökkent vagy
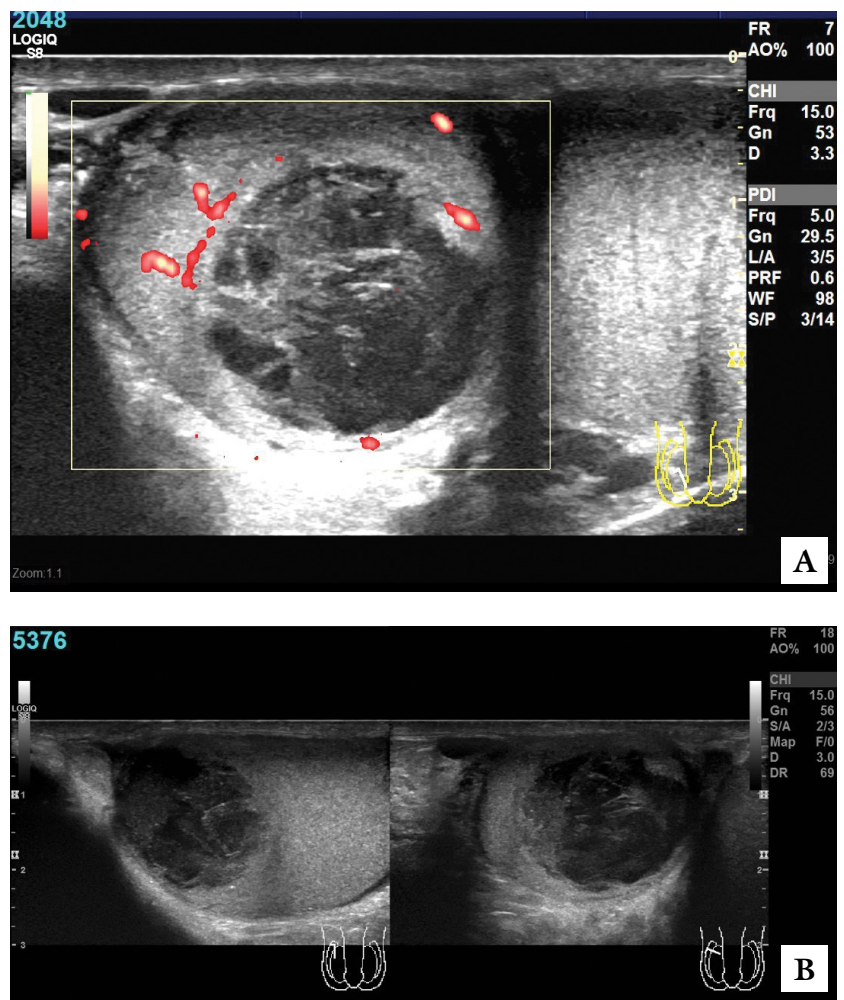

2. ábra

A 40 éves beteg kivizsgálása jobb oldali herébe sugárzó, éles, szúró fájdalmak miatt indult. A kivizsgálás keretein belül történt ultrahangvizsgálat során a jobb here felső pólusában $25 \mathrm{~mm}$ legnagyobb átmérójű echószegény, inhomogén képlet került leírásra (A ábra). Benne cystosus elemek láthatók, mely seminomára nem jellegzetes, valamint benne érzékeny paraméterekkel sem lehetett keringést detektálni. A terime körül a keringés fokozott (B ábra). Differenciáldiagnosztikai szempontból haematoma merül fel, annak ellenére, hogy a beteg a traumát negálja. Az ultrahanglelet birtokában a mútéti terv módosult. A mútét során haematoma került eltávolításra, valamint mintavétel is tör tént, mely malignitást nem igazolt 


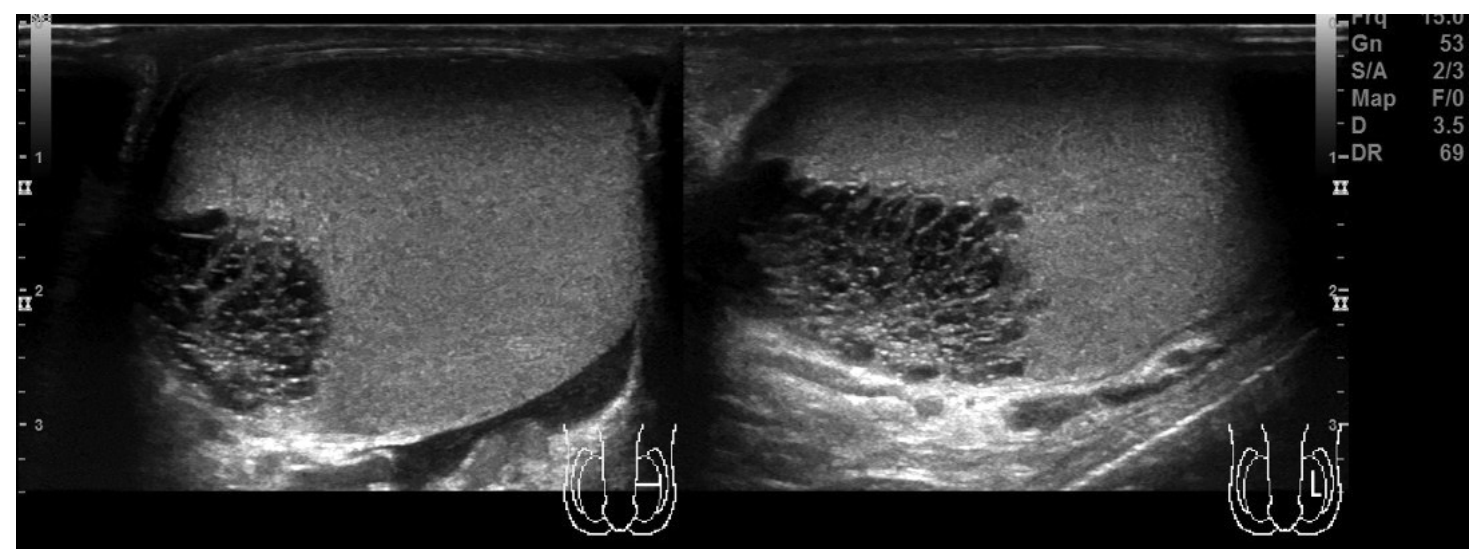

52 éves beteg, anamnézisében 5 éve bal oldali epididymitis és orchitis szerepelt. Jelenleg ismét a bal heréje fájdalmas. A tumormarkerek a normáltartományban vannak. A mediastinum testis helyét echószegény tubularis képletek foglalják el. A mellékherében egy nagyobb spermatokele is észlellhetó volt, az eltérést feltehetőleg szövődményesen gyógyult gyulladás okozhatta, mely a hegesedés miatt obstrukcióhoz vezetett

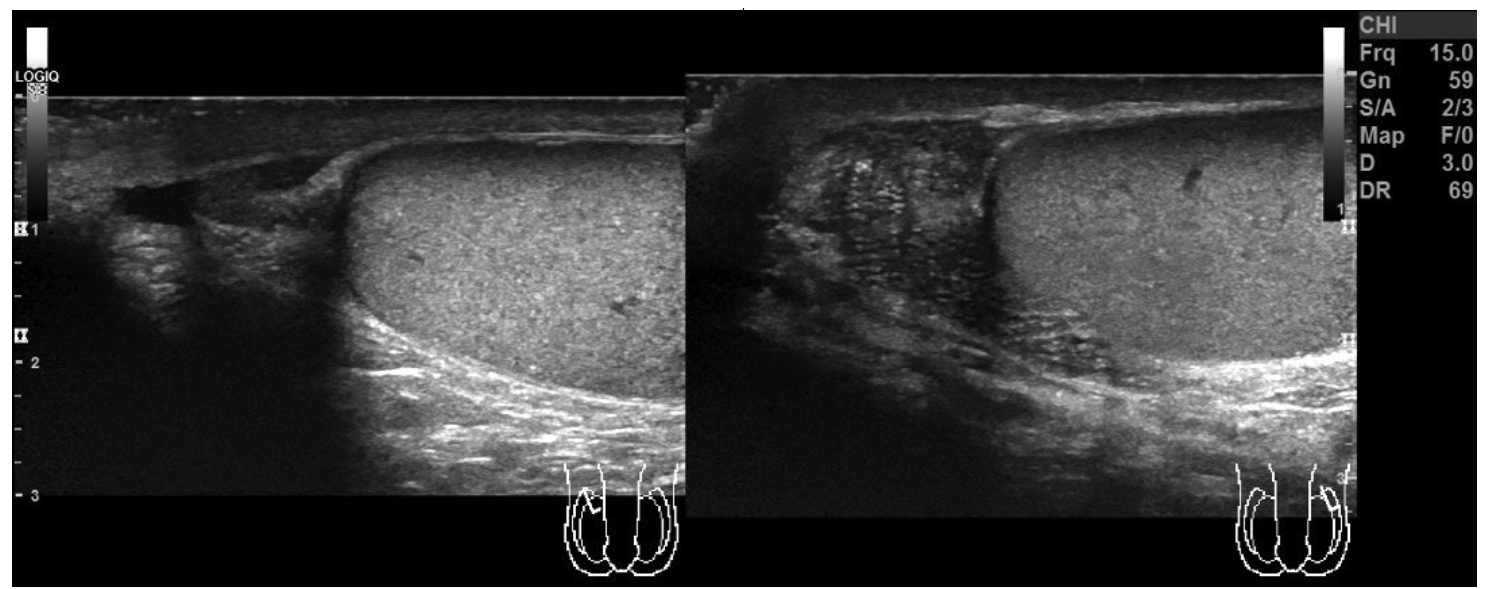

4. ábra

36 éves, oligoasthenozoospermiás beteg bal mellékheréje az ellenoldalinál jelentősen duzzadtabb, benne tág tubulusok látszanak, valamint látható volt a sperma áramlása

hiányzó vascularisatiót mutató eltérések esetében haematoma, szegmentális infarktus vagy krónikus károsodás merülhet fel $(2 / A$ és $2 / B$ ábra $)$.

Fontos a rete testis ectasia felismerése, amely együtt járhat obstrukcióval, és általában trauma után fordul elő, vagy gyulladás késői szövődményeként. Az elváltozás olyan apró echószegény, cysticus, kerek vagy ovális képletekből áll, melyekben keringés még érzékeny paraméterekkel sem detektálható. A mediastinum testist szélesíti ki vagy foglalja el teljesen, valamint általában spermatokelével együtt jár. Gyakrabban fordul elő idősebbeknél vagy olyan egyéneknél, akiknél vasectomia történt [28]. Régebben, az ultrahangvizsgálatok elterjedésének kezdetén könnyü volt összekeverni cystosus komponenst tartalmazó rosszindulatú elváltozásokkal, kevert eredetû tumorokkal [29] (3. ábra). Jellegzetes obstrukcióra utaló jel lehet az epididymis tubularis ectasiája. A mellékhere az ellenoldalihoz viszonyítva minden átmérőjében megnagyobbodott, vascularisatiója nem fokozott, benne számos apró echószegény tubularis képlet látható, melyet a mellékherében lévő ductusok tágulata okoz. Ezek a leletek a vas deferens elzáródására utalnak. Vasectomián átesettekben szerepet játszhat a postvasectomiás fájdalom kialakulásában [30], de előfordul sérvmútétek után is (4. ábra). Az azoospermiában szenvedő férfiak esetében fontos tudni, hogy az azoospermia obstruktív vagy nonobstruktív eredetü-e. Az ultrahangvizsgálat indirekt jelek alapján segíthet ennek megítélésében. Azoknál a betegeknél, akiknél az azoospermiát obstrukció okozza, a here mérete nem tér el a normozoospermiával rendelkező kontrollcsoportétól. Ugyanakkor szinte az összes betegnél észlelhetô volt az epididymis cystás vagy tubularis elváltozása. Ellenben nonobstruktív azoospermia esetében a here mérete szignifikánsan kisebb volt a kontrollcsoportban mértnél, és a mellékherében nem volt gyakrabban észlelhetố elváltozás [31, 32]. Más kutatások is megerősítették, hogy nonobstruktív azoospermia esetében a herék mérete kisebb, valamint az intra- és az extratesticularis varicokele is gyakrabban fordul elő. Ezzel szemben az obstruktív azoospermiában a ductalis ectasia, spermatokele és epididymitis fordul elő gyakrabban [33]. 


\section{A Doppler-vizsgálatok jelentősége}

A color-Doppler olyan, Doppler-elven múködő vizsgálat, amelynek során az áramlás sebességét és az áramlás irányát színkódolt kép segítségével tudjuk megjeleníteni. A transzducer felé irányuló áramlást piros, a transzducertől távolodó áramlást pedig kék színnel jelöljük. Ezen technika mellett napi rendszerességgel használjuk a powerDopplert, mely kisebb áramlási sebességek esetén ad jobb információt, mivel itt a mérés, a színkód az áramlás volumenével, nem pedig a sebességével arányos $[15,17]$.

A herében normálviszonyok esetén az intratesticularis artériákban diasztoléban magas anterográd áramlás mérhető, a herékben lévő alacsony ellenállásnak megfelelően. Az extratesticularis szöveteket ellátó artériákban a magas rezisztenciájú Doppler-görbe látható, mely jól tükrözi az extrascrotalis szövetek nagyobb ellenállását. Jellegzetes anatómiai variánsként a B-módú vizsgálatok során echószegény vaskos sávként jelenhet meg a transmediastinalis artéria, mely megközelítőleg a páciensek felében látható.

Urológiai vonatkozásban a módszer nélkülözhetetlen a heretorzió kimutatásában [16]. Segít elkülöníteni a torziót az akut gyulladástól - az epididymitistól és az orchitistől. A color-Doppler-ultrahangvizsgálat érzékenysége $80-98 \%$, specificitása pedig 97-100\% [16].

A Doppler-vizsgálatoknak a varicokele vizsgálatában szintén nagy jelentőségük van. Normális esetben a plexus pampiniformis vénáinak átmérôje $0,5-1,5 \mathrm{~mm}$ közötti, a fővéna átmérője megközelítóleg $2 \mathrm{~mm}$. Kóros esetben a vénák tággá, kifejezetten kanyargós lefutásúvá válnak. Meddő férfiak között a varicokele előfordulása gyakoribb. Elsődleges oka a vénákban lévő billentyúk elégtelen múködése. Másodlagos okként vénás elfolyási nehezítettség szerepelhet, melynek oka bizonyos esetekben tumor vagy az a. mesenterica superior általi v. renalis kompresszió lehet [34].

Mivel a jelenleg használatban lévő gépek, megfeleló beállítás esetén, az artériás áramlás jellemzésére több különböző Doppler-indexet is számítanak, kézenfekvő volt egyes betegségekben ezen indexek változásának vizsgálata, melyek közül a rezisztenciaindex $(\mathrm{RI}=$ szisztolés csúcssebesség - végdiasztolés sebesség / szisztolés csúcssebesség) a leghasznosabb. Annak ellenére, hogy már 1997-ben is vizsgálták a RI változását a különböző herebetegségekben, ez a mindennapos humán gyakorlatban nem terjedt el [35]. Állatokon, fóként tenyésztésre szánt versenylovakon végzett vizsgálatok alapján igazolták, hogy a szubfertilitáshoz általában magas vascularis rezisztenciára utaló Doppler-index-értékek társulnak [36]. Humán vizsgálatokban azt találták, hogy a 0,6-nél nagyobb intratesticularis RI-értékek $57 \%$-os szenzitivitással és 63\%-os specificitással jelzik a pathospermiát [37]. Az intratesticularis artériás véráramlás szignifikánsan csökken azoknál a férfiaknál, akiknél varicokelét diagnosztizáltak. Ezt okozhatja a károsodott mikrocirkuláció. A testicularis artériás véráram csökkenése a spermatogenesis károsodását okozhatja [12].

\section{Szonoelasztográfia}

A strain szonoelasztográfia a hazánkban használt legtöbb ultrahang-berendezésen hozzáférhető, az ultrahangkészülék-gyártók által felajánlott és megvásárolható opció. A módszer a szöveti rugalmasságot mutatja meg egy színkódolt képen, melyet elasztogramnak nevezünk. Az elasztogramot a transzducer finom, lassú hullámzó mozgatása során keltett szöveti deformálódás alapján kapjuk. Az elasztogram a vizsgált területen belüli szöveti struktúrák viszonylagos rugalmasságát színkóddal jelzi. A kék a rigid, míg a zöld, majd a piros színek az egyre lágyabb szöveteket jelölik. Amennyiben a nyomóerő ismert, a rugalmasság kvantitatív jellemzésére a Young-modulust (E) is kiszámíthatjuk a külső nyomóerő (S) és a deformitás mértékének (e) hányadosából. Szemikvantitatív elemzésre is van lehetőség, melynek során két megfelelő területen végzett méréssel deformációhányadost (strain ratio) számíthatunk [38-40].

A kisebb, intratesticularis eltérések differenciáldiagnózisában a szonoelasztográfia hasznos lehet, ugyanis ismert, hogy a malignus eltérések rigidebbé válnak, így az elasztogramon elkülönülnek a környezetüktől. A valós idejü elasztográfiás módszer, a hagyományos ultrahangos vizsgálómódszereknél (B-mód, color-Doppler) jobb, $100 \%$-os szenzitivitást és $81 \%$-os specificitást mutat az intratesticularis malignomák diagnosztikájában. Tehát, a szonoelasztográfia jól demonstrálja a tumorok szöveti rigiditását, s mivel negatív prediktív értéke $100 \%$ os, így a differenciáldiagnosztika elengedhetetlen eszközévé válhat [41].

Szintén megváltozhat a here szöveti rugalmassága a meddőség egyes típusaiban. A vizsgálatok alapja egy 5 fokozatú skála volt, amelyet a szonoelasztogramok alapján hoztak létre. Li és munkatársainak tanulmánya során az így kapott képet két radiológus vizsgálta egymástól függetlenül és helyezte el az 5 fokozatú skálán. Obstruktív azoospermia esetén a herék rigiditása az átlagostól szignifikánsan nem tér el, míg nonobstruktív azoospermiában a here rigidebbé válik. A kutatás során azt kapták, hogy a kétféle azoospermia között ez a skála szignifikánsan különbözik [42]. Azoospermiával diagnosztizált férfiak hereszövettani vizsgálata azt mutatta, hogy a ductuli seminiferi átméróje és a spermatogen epithelium vastagsága csökken, a lamina propria pedig megvastagodott. Feltételezhető, hogy emiatt is változik meg a here rugalmassága. A strain elasztográfia segítségével összefüggés található a strain ratio és az ondó spermiumkoncentrációja között. Kimutatták, hogy abnormális spermiogrameredménnyel rendelkező betegek körében negatív összefüggés van a teljes spermaszám és a strain ratio (scrotum subcutan zsír a here szövetéhez viszonyítva) között, továbbá hasonló korreláció mutatható ki a mozgó spermiumok számával és a hímivarsejtek morfológiájával is [43]. Igazolható továbbá az is, hogy a varicokelével diagnosztizált férfiak körében a here elaszticitása fordított 


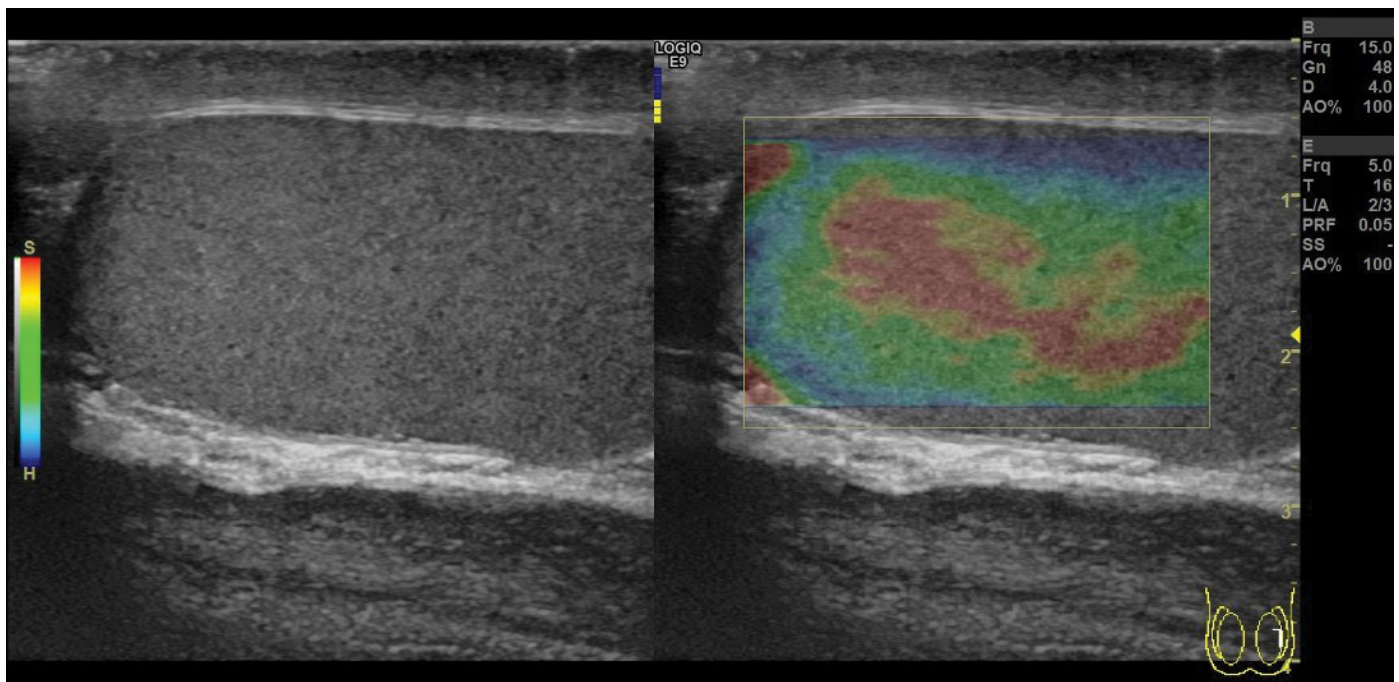

5. ábra

Normális here szonoelasztográfiás képe. A bal herérôl lineáris transzducerrel $(15,0 \mathrm{MHz})$ készített kép. A beteg varicokele miatt mútéten esett át, a spermiogramja normális

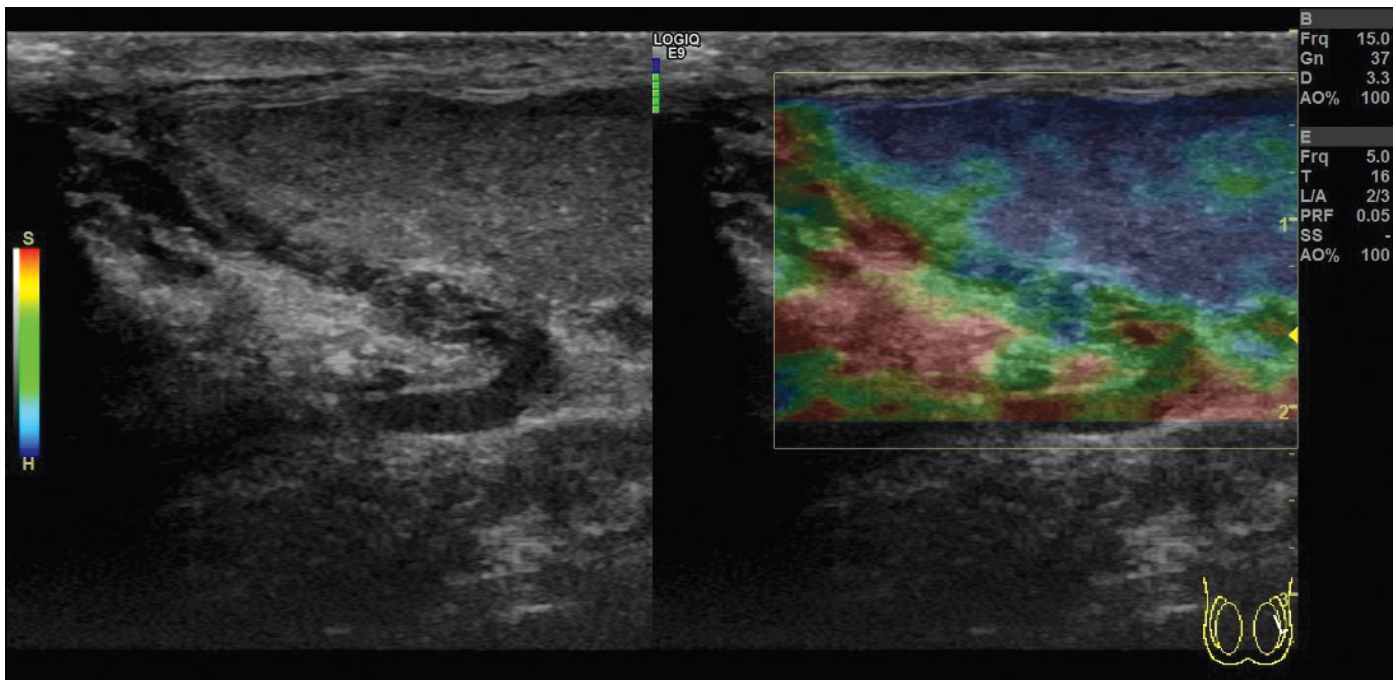

6. ábra

Jelentősen károsodott here szonoelasztográfiás képe. A bal heréról lineáris transzducerrel (15,0 MHz) készített kép. A beteg anamnéziséból kiemelendő, hogy prune belly szindrómával született. A jobb here heretorziót követóen atrofizált, a bal oldalon pedig retentio testis szerepel. A képen az átlagosnál kisebb, inhomogénebb, echószegényebb bal here látható, mely szonoelasztográfiával vizsgálva rigidebb a szokásosnál, ezt a színkódolt képen a kék szín jelzi. A beteg azoospermiás. A heréből végzett mikrosebészeti mintavétel szövettani eredménye: Johnsen score 1/10. Sertolli cell only szindróma

arányban áll a varicokele súlyosságával, valamint a szérum-FSH-értékkel is [44] (5., 6., 7. ábra).

A shear wave elasztográfia (SWE) napjainkban még kevésbé hozzáférhető eljárás. A módszer lényege, hogy a transzducer nem fókuszált ultrahangnyalábot bocsát ki a szövetre, hanem egy egyenes mentén különböző mélységekben több lökést hoz létre [40]. Az eljárást májbetegségekben, emlőben és pajzsmirigyben lévő gócok differenciáldiagnosztikájában használják. A vizsgált boxban a B-módú kép mellett szintén megjelenik egy színkódolt kép, de itt az előzőekkel ellentétben a színkód fordítva van. Kékkel van jelölve a lágyabb, pirossal pedig a rigidebb szövet [38]. Mivel az SWE az eddig ismertetett eljárok között a legösszetettebb, új lehetőségeket és ku- tatási irányokat is nyitott. A strain elasztográfiával megegyezően elsősorban a pajzsmirigygöbök és az emlő eltéréseinek differenciáldiagnosztikájában, valamint diffúz májbetegségekben (fibrosisban) használják. A meddőségi kivizsgálás során szerepét csak mostanában kezdik tisztázni. Zhang és mtsai állatkísérletes modellen vizsgálták, hogy a heretorzió milyen hatással lehet a spermium termelődésére. A kísérleti állatok, nyulak heréjében mütéti úton torziót hoztak létre, majd 24 óra múlva a torziót megszüntették. Az ultrahangos vizsgálatot elvégezték a beavatkozás után 24 órával és egy héttel. Később az állatok heréit eltávolították. A torzió során a here károsodása révén (oedema, necrosis, gyulladásos sejtek megjelenése) változik a here rugalmassága. Emiatt az SWE 


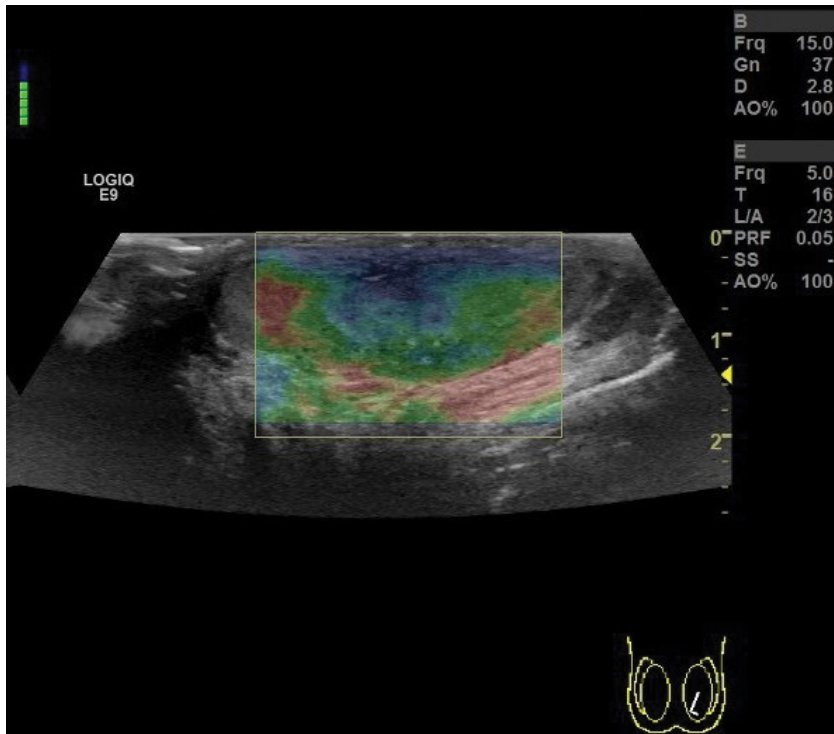

7. ábra

A normálisnál kisebb here szonoelasztográfiás képe. A jobb he rérôl lineáris transzducerrel $(15,0 \mathrm{MHz})$ készített kép. A színkódolt kép a normálistól kissé tér el. A beteg anamnéziséből kiemelendő az Addison-kór, a hypothyreosis, az emelkedett FSH- és prolaktinszint. A heréből végzett mikrosebészeti mintavétel szövettani eredménye: Johnsen score $5 / 10$, érési gátlás a spermatidák szintjén

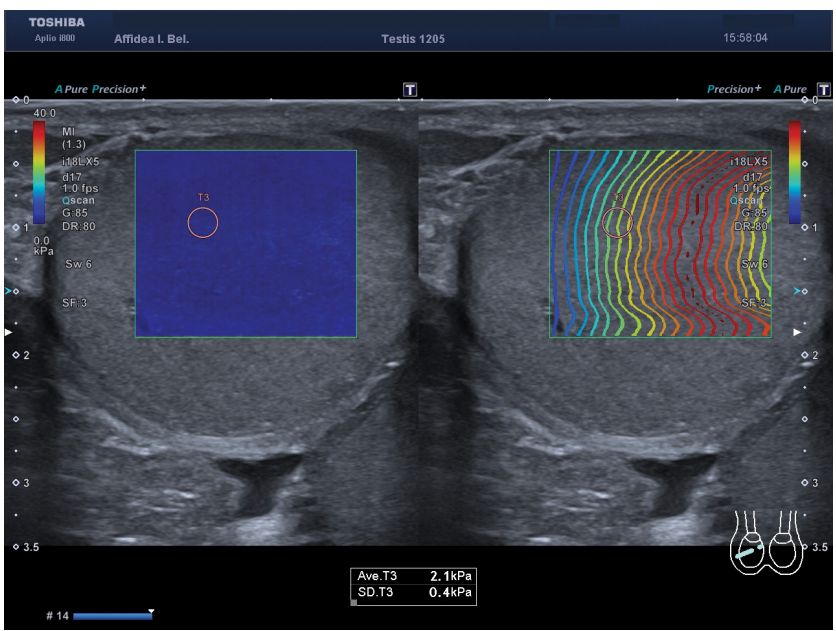

8. ábra

Azoospermiában szenvedő, mikrosebészeti mintavétel előtt álló férfi beteg. A shear wave elasztográfiás mérések során a here keménysége $3 \mathrm{kPa}$ alatt maradt, mely a normáltartománynak fele meg. A mintavétel szövettani eredménye: Johnsen score 10/10 normális spermiogenesis

által mérhető, és az így végzett mérések a szövettani feldolgozással, patológiai osztályozással összhangban voltak [45] (8. és 9. ábra).

\section{Következtetés}

Az utóbbi évtizedekben a képalkotó diagnosztika rohamosan fejlődött. Az újonnan megjelenő eljárások és technikák gyorsan megtalálták helyüket a betegségek diagnosztikájában, követésében és terápiájában is. A med-

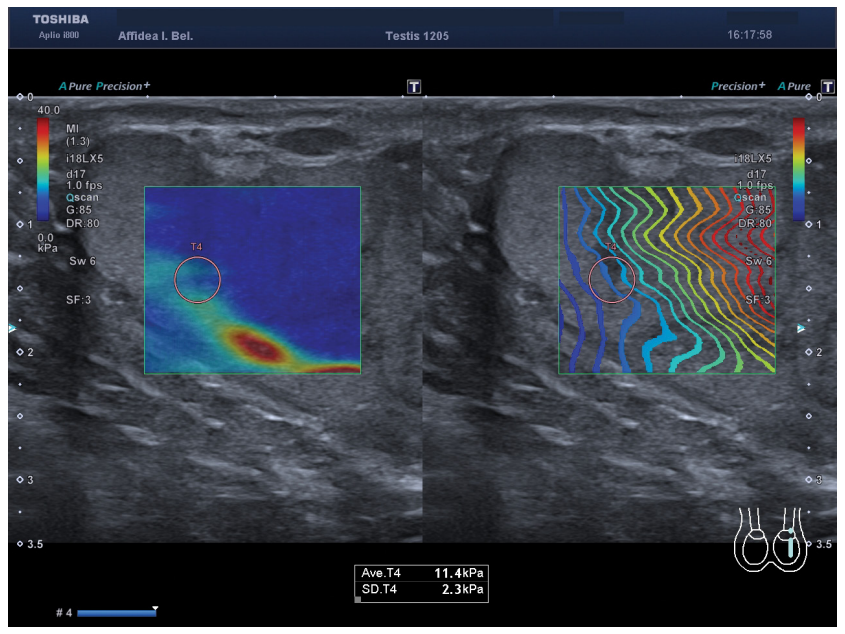

9. ábra

Azoospermiában szenvedő, mikrosebészeti mintavétel előtt álló férfi beteg. Jól látható a here inhomogenitása és eltérő keménysége, ennek megfelelóen a mért érték is magasabb tartományban, $3 \mathrm{kPa}$ felett van. A mútét során vett megfelelő méretű minta jelentős mennyiségű fibroticus szövetet tartalmazott, a kevés sejt miatt Johnsen score meghatározására nem volt alkalmas

dő párok kivizsgálása során, amennyiben nem normozoospermia látható, úgy a képalkotó eljárások közül az ultrahang-diagnosztika az első választandó vizsgálati technika, amely sok fontos információt adhat. Kimutathat intratesticularis, nem tapintható eltéréseket és segíthet differenciálni az obstruktív azoospermiát a nonobstruktív azoospermiától, ami egy esetleges beavatkozás és a mútéti technika megválasztásának szempontjából igen fontos lehet.

Kiemelendő továbbá a napjainkra már elterjedt szonoelasztográfia, egy olyan új differenciáldiagnosztikai eszköz, melynek lehetőségei még nem teljesen ismertek. Tumorok esetén olyan megbízható módszernek tünik, mellyel a dignitás jól értékelhető, így a mintavétel egyes esetekben elkerülhető. A Doppler-technikákkal ötvözve diagnosztikus értéke még tovább növelhető. A jövőben a szonoelasztográfia szerepe a férfimeddőség kivizsgálásában remélhetően egyre növekvő szerepet fog kapni, ezzel akár a diagnosztikus algoritmusban is olyan gyökeres változásokra kerülhet sor, melyek a betegek komfortérzetét növelik.

Anyagi támogatás: A közlemény megírása anyagi támogatásban nem részesült.

Szerzői munkamegosztás: F. Zs.: A vizsgálati szempontok kidolgozása a képalkotás szemszögéből, szakirodalmi másodelemzés, a kézirat szövegezése. P. N., K. I.: A vizsgálati szempontok kidolgozása klinikus oldalról, szakirodalmi másodelemzés, a kézirat szövegezése. B. Á., K. L.: Szakirodalmi másodelemzés és a kézirat szövegezése. M. Z., P. A.: A kézirat szövegezése. A cikk végleges változatát valamennyi szerző elolvasta és jóváhagyta.

Érdekeltségek: A szerzőknek nincsenek érdedkeltségeik. 


\section{Irodalom}

[1] Papp Z. Textbook of obstetrics and gynecology. [A szülészetnőgyógyászat tankönyve.] Semmelweis Kiadó, Budapest, 2017. [Hungarian]

[2] Ósapay Gy, Ösapay K. Stress and fertility. [A stressz és a fertilitás.] Orv Hetil. 2015; 156: 1430-1434. [Hungarian]

[3] Pásztor N. Male infertility. In: Kaáli Nagy G, Bártfai Gy. (eds.) Up-to-date diagnosis and therapy of infertility. [Férfi eredetú meddőség. In: Kaáli Nagy G., Bártfai Gy. (szerk.) A meddőség korszerú diagnosztikája és kezelése.] Medicina Könyvkiadó, Budapest, 2018; pp. 121-168. [Hungarian]

[4] Kratochwil VA. The place of ultrasound diagnosis in urology. Wien Klin Wochenschr. 1975; 87: 385-388.

[5] Miskin M, Buckspan M, Bain J. Ultrasonographic examination of scrotal masses. J Urol. 1977; 117: 185-188.

[6] Mullins TL, Sant GR, Ucci AA Jr, et al. Testicular microlithiasis occurring in postorchiopexy testis. Urology 1986; 27: 144-146.

[7] Mackinnon J, Coz F, Díaz L. Testicular microlithiasis: echographic diagnosis of a new cause of orchialgia and infertility. Rev Chil Obstet Ginecol. 1990; 55: 6-9.

[8] Milleret R, Liaras H. Auscultation using ultrasound in torsion of the testicle. (Diagnostic and therapeutic importance). J Chir (Paris). 1974; 107: 35-38.

[9] Berényi P, Korányi L. Ultrasound diagnostics of leasions of epidimis and testis. [A here és a mellékhere elváltozásainak ultrahangdiagnosztikája.] Magy Urol. 1989; 1: 33-37. [Hungarian]

[10] Járay A, Giyab O, Miklós K, et al. Technical prerequisites and methodology of contrast enhanced ultrasound examinations. [A kontrasztanyagos ultrahangvizsgálatok technikai feltételei és vizsgálati módszerei.] Magy Radiol. 2012; 86: 74-82. [Hungarian]

[11] Buzás GyM, Harkányi Z, Baranyai T, et al. (eds.) The history of clinical ultrasound diagnostic in Hungary. [A klinikai ultrahangdiagnosztika története Magyarországon.] Akadémiai Kiadó, Budapest, 2008. [Hungarian]

[12] Schurich M, Aigner F, Frauscher F, et al. The role of ultrasound in assessment of male fertility. Eur J Obstet Gynecol Reprod Biol. 2009; 144(Suppl 1): S192-S198.

[13] Vandaele P, Marcelli F, Ouzzane A, et al. Testicular nodules of infertile men and contrast enhanced ultrasonography: preliminary study. Prog Urol. 2015; 25: 274-281.

[14] Géczi L, Horváth Zs, Beczássy E, et al. Early diagnosis of testicular cancers. [A heredaganatok korai diagnózisa.] Magy Onkol. 2000; 44: 275-283. [Hungarian]

[15] Harkányi Z, Morvay Z. Ultrasonography. [Ultraszonográfia.] Minerva Kiadó, Budapest, 2006. [Hungarian]

[16] Beliczay B, Mavrogenis S, Majoros A, et al. The partial ischemic infarction of the testis. [A here részleges iszkémiás infarktusos elhalása.] Magy Urol. 2012; 24: 78-81. [Hungarian]

[17] Gorman B. The scrotum. In: Rumack CM, Wilson SR, Char boneau JW, et al. (eds.) Diagnostic ultrasound, 4th edition. Mosby, Philadelphia, PA, 2011; Vol. 1, Chapter 21, pp. 840-877.

[18] Harkányi Z, Morvay Z. (eds.) How to examine with ultrasound? [Hogyan vizsgáljunk ultrahanggal?] Medicina Könyvkiadó, Budapest, 2015. [Hungarian]

[19] Meiner A, Mamoulakis C, de la Rosette JJ, et al. Clinical update on testicular microlithiasis. Curr Opin Urol. 2009; 16: 615-618.

[20] Jungwirth A, Giwercman A, Tournaye H, et al, EAU Woking Group on Male Infertility. European Association of Urology Guidelines on Male Infertility: The 2012 Update. Eur Urol 2012; 62: 324-332

[21] Skakkebaek NE, Rajpert-De Meyts E, Main KM. Testicular dysgenesis syndrome. An increasingly common developmental disorder with environmental aspects. Hum Reprod. 2001; 16: 972-978.

[22] van Casteren NJ, Looijenga LH, Dohle GR. Testicular microlithiasis and carcinoma in situ: overview and proposed clinical guideline. Int J Androl. 2009; 32: 279-287.

[23] Backus ML, Mack LA, Middleton WD, et al. Testicular microlithiasis: imaging appearances and pathologic correlation. Radiology 1994; 192: 781-785
[24] Pedersen MR, Graumann O, Hørlyck A, et al. Inter- and intraobserver agreement in detection of testicular microlithiasis with ultrasonography. Acta Radiol. 2016; 57: 767-772.

[25] Sanli O, Kadioglu A, Atar M, et al. Grading of classical testicular microlithiasis has no effect on the prevalence of associated testicular tumors. Urol Int. 2008; 80: 310-316.

[26] Takács T, Gulácsi A, Riesz P, et al. The importance of testicular microlithiasis. [A here microlithiasisának jelentősége napjainkban.] Magy Urol. 2013; 25: 63-66. [Hungarian]

[27] Woodward PJ, Sohaey R, O'Donoghue MJ, et al. From the archives of the AFIP: tumors and tumorlike lesions of the testis: radiologic-pathologic correlation. Radiographics 2002; 22: 189-216.

[28] Ishigami K, Abu-Yousef MM, El-Zein Y. Tubular ectasia of the epididymis: a sign of postvasectomy status. J Clin Ultrasound 2005; 33: 447-451.

[29] Tartar VM, Trambert MA, Balsara ZN, et al. Tubular ectasia of the testicle: sonographic and MR imaging appearance. Am J Roentgenol. 1993; 160: 539-542.

[30] Saboo SS, Brodsky GL, Di Salvo D. Sonographic-pathologic cor relation of epididymal changes in a suspected case of postvasec tomy pain syndrome. J Ultrasound Med. 2012; 31: 973-974.

[31] Liu J, Wang Z, Li M, et al. Differential diagnostic value of obstructive and nonobstructive azoospermia by scrotal ultrasound. Ultrasound Q. 2017; 33: 272-275.

[32] Du J, Li FH, Guo YF, et al. Differential diagnosis of azoospermia and etiologic classification of obstructive azoospermia: role of scrotal and transrectal US. Radiology 2010; 256: 493-503.

[33] Abdulwahed SR, Mohamed EE, Taha EA, et al. Sensitivity and specificity of ultrasonography in predicting etiology of azoospermia. Urology 2013; 81: 967-971.

[34] Beddy P, Geoghegan T, Browne RF, et al. Testicular varicoceles. Clin Radiol. 2005; 60: 1248-1255.

[35] Jee WH, Choe BY, Byun JY, et al. Resistive index of the intrascrotal artery in scrotal inflammatory disease. Acta Radiol. 1997; 38: 1026-1030.

[36] Ortiz-Rodriguez JM, Anel-Lopez L, Martín-Muñoz P, et al. Pulse Doppler ultrasound as a tool for the diagnosis of chronic testicular dysfunction in stallions. PLoS ONE 2017; 12: e0175878.

[37] Hillelsohn JH, Chuang KW, Goldenberg E, et al. Spectral Doppler sonography: a noninvasive method for predicting dyspermia J Ultrasound Med. 2013; 32: 1427-1432.

[38] Sarvazyan AP. Elastic properties of soft tissue. In: Levy M, Bass HE, Stern RR. (eds.) Handbook of elastic properties of solids, liquids and gases. Academic Press, New York, NY, 2001; pp. 107-127.

[39] Meszlényi RJ, Dóczi R. The variegation of the sonoelastography and the directions of its developments. [A szonoelasztográfiás módszerek sokszínúsége és a fejlesztések irányai.] Magy Radiol. 2013; 87: 29-32. [Hungarian]

[40] Újlaki M, Bahéry M, Gődény M. Sonoelastographic techniques and radiology. [Szonoelasztográfiás módszerek és radiológia.] Magy Radiol Online 2015; 6 (9). [Hungarian]

[41] Aigner F, De Zordo T, Pallwein-Pretteóner L, et. al. Real-time sonoelastography for the evaluation of testicular leasions. Radiology 2012; 263: 584-589.

[42] Li M, Du J, Wang ZQ, et al. The value of sonoelastography scores and the strain ratio in differential diagnosis of azoospermia. J Urol. 2012; 188: 1861-1866.

[43] Küçükdurmaz F, Sarıca MA, Emre Ö, et al. Evaluation of the diagnostic efficacy of strain elastography in infertile population with normal and abnormal semen parameters. Turk J Urol. 2017; 43: 261-267.

[44] Dede O, Teke M, Daggulli M, et al. Elastography to assess the effect of varicoceles on testes: a prospective controlled study. Andrologia 2016; 48: 257-261.

[45] Zhang X, Lv F, Tang J. Shear wave elastography (SWE) is reliable method for testicular spermatogenesis evaluation after torsion. Int J Clin Exp Med. 2015; 8: 7089-7097.

(Fejes Zsuzsanna dr., Szeged, Semmelweis u. 6/A, 6725 e-mail: dr.fejes.zsuzsanna@gmail.com) 